ks. Grzegorz Bachanek

UKSW Warszawa

DOI: $10.15290 /$ std.2015.01.03

\title{
PSYCHOLOGIA A TEOLOGIA. MIEJSCA SPOTKANIA W ANTROPOLOGICZNEJ REFLEKSJI J. RATZINGERA
}

\section{PSYCHOLOGY AND THEOLOGY. THE ROLE OF REUNION IN THE ANTHROPOLOGICAL REFLECTION OF J. RATZINGER}

Ratzinger shows a deep appreciation for Saint Augustine, the one among the Church Fathers who is known for his work on the interior, emotional world of man's experience. He draws on the reflections of the renown $20^{\text {th }}$ century psychologist Albert Görres and cites the works of C.G. Jung. By defending the truth about the creation, Ratzinger defends the meaning of the human psyche. Combining both psychological and theological research, he turns the reader's direction to the reality of human sin and guilt, emphasizing the healing power of faith, prayer and the sacraments. Ratzinger also expresses his concern for people with mental disabilities, who he views as the privileged children of the Creator. He encourages mental hygiene and stresses how, when treated as a priority, the sacrament can have a positive influence on the mental well being of any person. He stresses the specifics of theology, which cannot be reduced to a science. Above all, the author emphasizes the truth about Christ, who brings salvation to humankind. Salvation cannot be attained through psychological means, without God, who is identified as the construction point of human existence.

Key words: theology, psychology, anthropology, J. Ratzinger, Benedict XVI. 
Popularność psychologii we współczesnym społeczeństwie stanowi zachętę do pytania, jak J. Ratzinger widzi wzajemną relację psychologii i teologii. Jak spotykały się one w jego refleksji dotyczącej ludzkiej osoby? Poniższy artykuł stanowi próbę odpowiedzi na te pytania.

\section{Patrystyczne i współczesne inspiracje}

Jak wiemy, niemiecki teolog często odwołuje się do myśli św. Augustyna. Przypominając postać tego wielkiego mistrza teologii zwraca uwagę na jego Wyznania. Widzi w nich dzieło skoncentrowane na wnętrzu człowieka i jego psychologii, ale równocześnie poprzez ludzkie „ja” ukazujące misterium Boga. Dzieło to jest jedyne i niezwykłe w swoim rodzaju ${ }^{1}$. Poprzez ten przykład św. Augustyna, zdaje się wskazywać Benedykt, że między skupieniem uwagi na tajemnicy ludzkiego wnętrza a głoszeniem chwały Boga, między psychologią a duchowością nie musi istnieć nieusuwalny konflikt. Podobnie jak u teologa z Hippony możemy dostrzec u autora glębokie zainteresowanie bogactwem ludzkiego wnętrza.

Ratzinger odwołuje się do psychologicznej analizy pokusy św. Cypriana, dla którego pokusa może być rodzajem pokuty, która chroni nas przed pychą. Pozwala doświadczyć kruchości naszej wiary, nadziei i miłości. Przypomina o konieczności łaski. Chroni przed złudzeniem, że naszą wielkość zawdzięczamy sobie $^{2}$. Widzimy, że przynajmniej niektórzy z Ojców Kościoła łączą refleksję teologiczną i psychologiczną.

Gdy chodzi o współczesnych autorów, Ratzinger wspomina swoją współpracę z psychologiem Albertem Görresem ${ }^{3}$ w redagowaniu czasopisma „Communio”4. W jednej ze swoich prac odwołuje się do współczesnej kultury masowej, a konkretnie fascynacji piłką nożną. Widzi tutaj ludzką tęsknotę za powrotem do Raju, życiem sytym i radosnym, wyjściem z powagi codzienności. Równocześnie gra wprowadza do życia, zmusza do samodyscypliny, do współpracy z innymi, poszanowania zasad gry ${ }^{5}$. W tych rozważaniach można dostrzec wrażliwość na

$1 \quad$ Por. Benedykt XVI, Katechezy o Ojcach Kościoła, Kraków 2008, s. 158.

2 Por. J. Ratzinger/Benedykt XVI, Jezus z Nazaretu, cz. 1, Od Chrztu w Jordanie do Przemienienia, Kraków 2007, s. 143. Por. Cyprian z Kartaginy, De dominica oratione, w: Thasci Caecilli Cypriani Opera omnia, CSEL III 1, s. 265-294.

3 Albert Görres (†1996) - to wybitny niemiecki psychoanalityk i psychoterapeuta, który po uzyskaniu habilitacji z psychologii kierował pierwszą niemiecką katedrą psychologii głębi na uniwersytecie w Moguncji, przez wiele lat związany z uniwersytetami Monachium.

4 Por. J. Ratzinger, Moje życie. Wspomnienia z lat 1927-1977, Częstochowa 1998, s. 129.

$5 \quad$ Por. idem, Stużyć prawdzie. Myśli na każdy dzień, Wrocław 2001, s. 269. 
świat ludzkich pragnień, emocji i próbę dostrzeżenia w nich także elementów pozytywnych.

\section{Godność człowieka, szczególnie chorego}

Otwierając w Watykanie w 1996 roku XI Międzynarodową Konferencję, poświęconą chorobom umysłowym, zorganizowaną przez Papieską Radę ds. Duszpasterstwa Służby Zdrowia, kardynał Ratzinger przypomniał postać swojego kuzyna dotkniętego zespołem Downa, który został zamordowany przez nazistów. Podkreślał, że Pan Bóg nie ocenia człowieka według jego inteligencji czy zdrowia. Chorzy są uprzywilejowanymi dziećmi Stwórcy. W Kościele było i jest dla nich miejsce ${ }^{6}$. Człowiek cierpiący z powodu niedorozwoju umysłowego czy chorób psychicznych jest ukochany przez Boga. Służba temu człowiekowi stanowi miejsce spotkania Kościoła i psychiatrii, psychologii czy psychoterapii.

Benedykt zwracając się do stałych diakonów w Afryce prosi ich o szczególną troskę wobec osób chorych psychicznie lub fizycznie, najsłabszych i najuboższych. Zachęca, by ich miłosierdzie było twórcze? ${ }^{7}$ Papież zna często trudną sytuację osób chorych psychicznie w Afryce, gdzie w wielu rodzinach brakuje szacunku dla tych osób.

Autor uważa, że cierpienia psychiczne raczej nasiliły się w ciągu ostatnich dziesięcioleci. Powinniśmy lagodzić cierpienia, ale całkowite usunięcie ich ze świata nie leży w zasięgu naszych możliwości. Nie jesteśmy w stanie usunąć naszej skończoności, wyeliminować mocy zła i winy ${ }^{8}$. Realizm nakazuje uznanie niemożności usunięcia cierpienia z ludzkiej egzystencji, co oczywiście nie oznacza bezczynności czy obojętności.

Kościół odpowiada na głębokie potrzeby człowieka. Odwrót od Kościoła i chrześcijaństwa, jaki obserwowaliśmy w ostatnich kilkudziesięciu latach był jedną z przyczyn, które doprowadziły do ruiny ludzkiej psychiki, do zagubienia orientacji ${ }^{9}$. Jedną z ideologii dokonującą głębokiego spustoszenia w psychice jest radykalny feminizm. Macierzyństwo i dziewictwo stają się wartościami nieakceptowanymi przez dominującą kulturę. Kobieta zostaje poddana ideologii maskulinistycznej, kulturze, w której najwyżej oceniana jest produkcja,

6 Por. Z. J. Ryn, Na obraz i podobieństwo Boże - czy zawsze?, „L’Osservatore Romano” 1997 nr 3, s. 53.

7 Por. Benedykt XVI, Adhortacja Africae munus, 116

8 Por. idem, Spe salvi, 36.

9 Por. Sól ziemi. Chrześcijaństwo i Kościót katolicki na przełomie tysiącleci. Z kardynałem Josephem Ratzingerem rozmawia Peter Seewald, Kraków 2005, s. 14. 
wydajność, zysk ${ }^{10}$. Obrona chrześcijaństwa stanowi obronę człowieka także w wymiarze jego psychiki.

W obliczu rozwijających się ruchów ekologicznych Ratzinger zachęca do ekologii psychicznej. Zanieczyszczenie środowiska jest konsekwencją zanieczyszczenia środowiska wewnętrznego. Słabą stroną ruchów ekologicznych jest zapominanie o tym zanieczyszczeniu ludzkiej psychiki. Człowiek w swoim wnętrzu jest stworzeniem Bożym, mającym pochodzący od Boga porządek. Musi nauczyć się akceptować siebie jako Boże stworzenie i dbać o wewnętrzną czystość. Dopóki będzie rozumiał wolność jako wolność wewnętrznej, psychicznej destrukcji będzie postępowało zniszczenie środowiska naturalnego ${ }^{11}$. Autor zwraca się do ludzi zafascynowanych ekologią. Zachęca do dostrzeżenia związku między zatruciem środowiska naturalnego a wcześniejszym zatruciem ludzkiego wnętrza przez moralne zło.

Zaskakująca decyzja Benedykta XVI z 10 lutego 2013 roku wywołała powszechne zdumienie. Tym niemniej możemy dostrzec wcześniejszą zapowiedź wskazującą na taką możliwość: „Gdy papież wyraźnie widzi, że fizycznie, psychicznie i duchowo nie może już dłużej poradzić sobie ze swoim urzędem, wtedy ma on prawo, a w niektórych sytuacjach nawet obowiązek, zrezygnować" ${ }^{12}$. H. Maier krytycznie oceniał: „Obawiam się, że prawne myślenie Kościoła nie odkryło jeszcze faktu istnienia człowieka omylnego, ograniczonego przez swe możliwości psychiczne i fizyczne, człowieka, który skazany jest na uzupełnienie i kontrolę ze strony innych ludzi" ${ }^{13}$. Wydaje się, że w trudnej i bolesnej decyzji Benedykta XVI o rezygnacji z urzędu piotrowego można dostrzec uznanie granic własnych możliwości.

Autor odwołuje się do poglądów Romano Guardiniego. Dla tego myśliciela życie człowieka jest nietykalne, ponieważ jest on osobą. Rozumie przez to nie jakieś zjawisko psychologiczne, ale ludzkie istnienie. Bycie osobą nie zależy od wieku, stanu psychicznego czy naturalnych talentów. Żadna ludzka istota nie może być traktowana jak rzecz, także człowiek śpiący, dziecko, umysłowo chory czy ludzki płód ${ }^{14}$.

Ksiądz J. Szymik przypomina, że Ratzinger broni podstawowej prawdy o człowieku, o jego szczególnej godności, o jego wyrastaniu ponad świat zwierząt: Albo - kolejna

10 Por. J. Ratzinger, Raport o stanie wiary, Marki 2005, s. 83.87n.

11 Por. Sól ziemi. Chrześcijaństwo i Kościót katolicki..., s. 198n.

12 Benedykt XVI w rozmowie z Peterem Seewaldem, Świattość świata. Papież, Kościót i znaki czasu, Kraków 2011, s. 42.

13 H.Maier, Getto emancypacji-przeczytane ponownie, w: J. Ratzinger, H. Maier, Demokracja w Kościele. Możliwości i ograniczenia, Kraków 2004, s. 142.

14 Por. J. Ratzinger, Europa Benedykta w kryzysie kultur, Częstochowa 2005, s. 88n. 
możliwość - manipulacyjne, quasi-naukowe zacieranie różnic między człowiekiem i zwierzęciem (na terenie socjologii, psychologii zwierząt itp. itd.), przy milczącej (albo i głośnej) zgodzie na przenoszenie ewolucyjnego modelu nauk przyrodniczych na historię ducha. „Procesy duchowe nie trzymają się tych samych praw, co genealogiczne drzewa zwierząt" - tłumaczył jako Kardynał15.

Prawda o człowieku może być zacierana, jego nienaruszalna godność może być kwestionowana także na terenie psychologii, gdy gubi ona swoją humanistyczną specyfikę. Ukazuje się tutaj potrzeba, by Kościół z odwagą wchodził w spór z niektórymi nurtami współczesnej psychologii.

\section{Akceptacja prawdy o stworzeniu}

Odwołując się do doświadczenia psychiatrów autor uznaje, że najgłębszą przyczyną schorzeń psychicznych jest brak jedności człowieka z samym sobą, konflikt z własną naturą, niezgoda na własne „ja”. Dopiero akceptując siebie jestem zdolny zaakceptować drugiego. W wierze w Stwórcę, od którego pochodzi moje „ja” ze wszystkimi jego ograniczeniami znajduje swoje źródło ludzka miłość ${ }^{16}$. Autor wskazuje na związek między wiarą w stworzenie a zdrowiem psychicznym.

Gdy w katechezie odsuwamy na margines prawdę o stworzeniu, ulega redukcji obraz Boga, a w związku z tym i chrystologia. Fenomen religii nie znajduje wówczas wytłumaczenia poza sferą psychologiczną i socjologiczną ${ }^{17}$.

Ratzinger ostrzega przed dwoma niebezpieczeństwami. Krytykuje Skinnera ${ }^{18}$, który wychodząc od psychologii próbuje odrzucić ludzkiego ducha i ludzką wolność, zachęcając człowieka, by powrócił do równowagi wyzwalając się ze swego człowieczeństwa. Próba ta w różnych formach nihilizmu staje się coraz większą pokusą dla zachodniej młodzieży ${ }^{19}$.

Z drugiej strony dostrzega niebezpieczeństwo monizmu łaski, polegające na odwróceniu właściwej kolejności chrześcijańskiej pedagogiki. Nie powinno się pomijać właściwej kolejności: najpierw to, co psychiczne, potem to, co duchowe. Chrześcijańska miłość musi obejmować także przyjęcie mnie samego

15 J. Szymik, Theologia Benedicta, t. II, Katowice 2012, s. 193n.

16 Por. J. Ratzinger, Stużyć prawdzie. Myśli na każdy dzień, Wrocław 2001, s. 302.

17 Por. idem, Przekaz wiary i źródta wiary, „Więż” 1984 nr 2/3, s. 138.

18 Burrrhus Frederic Skinner (†1990) to amerykański psycholog, jeden z twórców i najważniejszych przedstawicieli behawioryzmu.

19 Por. J. Ratzinger, Na poczattu Bóg stworzyt... Cztery kazania o stworzeniu i upadku. Konsekwencje wiary w stworzenie, Kraków 2006, s. 92. 
jako stworzenia ${ }^{20}$. Autor wydaje się uważać odrzucenie znaczenia sfery ludzkiej psychiki za jedną z form odrzucenia idei stworzenia w myśli współczesnej.

\section{Potrzeba prawdy i miłości}

Rozważając znaczenie święta Bożego Ciała, autor zwraca uwagę na kwestię pamięci. Sobór Trydencki podkreśla, że Boże Ciało ma przypominać o Panu obecnym w Eucharystii i budzić wdzięczność. Psychologowie podkreślają, że racjonalna świadomość jest tylko powierzchnią naszej duszy. Żyjemy pochłonięci tą powierzchnią uciekając przed głębią. Człowiek nie słyszy tego, co istotne, nie żyje własnym życiem. Prowadzi to do jego choroby. Nie przyjmujemy do wiadomości starzenia się i śmierci, wchodzimy w kłamstwo. Tymczasem jedynym sposobem rzeczywistego radzenia sobie $z$ czasem jest przyjęcie go jako daru i postawa wdzięczności ${ }^{21}$. Autor wskazuje na kwestię ucieczki człowieka przed własną egzystencją, rzeczywistością zbliżającej się śmierci, problem swego rodzaju zawinionego zapominania, które prowadzi do choroby.

Ewangelia św. Jana opiera się na przypominaniu przez ucznia i Kościół czynów i słów Jezusa. Chodzi tutaj o głębsze poznanie rzeczywistości i dostrzeżenie prawdy ukrytej w fakcie. Trzyma się rzeczywistych wydarzeń, a równocześnie wychodzi poza zewnętrzną stronę faktów. Nie jest to proces wyłącznie psychologiczny czy umysłowy, ale czynność dokonująca się w Duchu Świętym. Duch ukazuje wewnętrzne związki Pisma i powiązania słów z rzeczywistością. Nie jest to sprawa prywatna, ale dotycząca wspólnoty przypominających sobie, pamięci Kościoła. Ewangelia otwiera drogę coraz głębszego poznawania całej prawdy w kolejnych pokoleniach ${ }^{22}$. Potrzeba prawdy dotyczy poszczególnego człowieka, ale i całego Kościoła.

Przemawiając do wypędzonych wskazuje Ratzinger, że nie można przemilczać niesprawiedliwości wypędzenia Niemców po II wojnie światowej. Psychologia mówi nam, że przemilczanie nie przynosi żadnego rozwiązania, a zatruwa od wewnątrz. Odnosi się to nie tylko do życia jednostek ale i do narodów. Tylko przyjęcie prawdy może uzdrawiać. Tylko przez miłość prawda staje się pełna sensu. Tylko przez pojednanie może zostać przezwyciężona nienawiść, przerwany łańcuch zła. Zadaniem wypędzonych jest budowanie mostów pojednania, bycie filarami nowej Europy ${ }^{23}$.

20 Por. ibidem, s. 92-94.

21 Por. J. Ratzinger, Święto wiary. O teologii mszy świętej, Kraków 2006, s. 124n.

22 Por. J. Ratzinger/Benedykt XVI, Jezus z Nazaretu, cz. 1, Od Chrztu w Jordanie do Przemienienia, Kraków 2007, s. 198-200.

23 Por. J. Ratzinger, Brücke der Einheit und Versöhnung. Pfingstpredigt beim Gottesdienst zum Sudetendeutschen Tag in München am 3.6.1979, München 1979, s. 3n. 
„W następstwie Freuda uwierzyliśmy w to, że ojciec jest koszmarem superego, który staje na drodze naszej wolności i którego musimy się pozbyć. A teraz, gdy tak się stało, uświadamiamy sobie, że wyemancypowaliśmy się przy tym z miłości i amputowaliśmy sobie to, co nam pozwala żyć" ${ }^{24}$. Kryzys ojcostwa wiąże Ratzinger z myślą Zygmunta Freuda. Kryzys ten oznacza także ucieczkę od miłości.

Chrześcijanin nie może powiedzieć, że każdy powinien zachować tę religię, która stała się jego udziałem. W takiej sytuacji religia straciłaby związek z prawdą, stałaby się czystą tradycją. Zostałaby przeniesiona do sfery psychologii czyli subiektywnego doświadczenia i postaw i socjologii tzn. rytuałów życia wspólnego. Przestałaby zbliżać ludzi do siebie ${ }^{25}$. Albert Görres pisze o chrześcijaninie naszych czasów, który wybiera sobie taki koktajl poglądów, jakie mu najlepiej smakują ${ }^{26}$. W rozważaniach na temat prawdy Ratzinger odwołuje się do zdania monachijskiego psychologa, który zwraca uwagę na niebezpieczeństwo hinduizacji chrześcijaństwa. Jezus nie chciał wywołać jakiegoś beztreściowego wzruszenia, nie przyznawał każdemu racji. Jego nauczanie zawiera zasadę dogmatyczną. Katolicy wierzą, że istnieją konieczne kontury wiary, że Kościół powinien troszczyć się, by pokazywać całość Objawienia bez ograniczeń i zniekształceńn ${ }^{27}$.

Człowiek został stworzony przez Boga jako potrzebujący prawdy i miłości. Gdy przed nimi ucieka, jego życie traci swoje ukierunkowanie, a tym samym sens.

\section{Tajemnica ludzkiego grzechu}

W dyskusji na temat sumienia Ratzinger powołuje się na poglądy A. Görresa, który wskazuje, że poczucie winy jest niezbędne człowiekowi tak samo jak ból fizyczny. Tak jak ból fizyczny pozwala dostrzec, że ludzki organizm nie funkcjonuje prawidłowo, tak poczucie winy burzy fałszywy spokój sumienia. Poczucie winy jest potrzebne każdemu człowiekowi. Być może były go pozbawione takie postacie jak Hitler, Himmler czy Stalin. Być może nie posiadają go przywódcy mafii ${ }^{28}$. To nie poczucie winy jako takie jest czymś chorobliwym, ale jego brak stanowi oznakę duchowej choroby.

24 J. Ratzinger, Głosiciele i studzy Waszej radości. Teologia i duchowość sakramentu święceń, „Opera omnia” t. XII, Lublin 2012, 658.

25 Por. idem, W drodze do Jezusa Chrystusa, Kraków 2004, s. 81.

26 Por. idem, Gottes Projekt. Nachdenken über Schöpfung und Kirche, Regensburg 2009, s. 123.

27 Por. idem, Prawda w teologii, Kraków 2005, s. 106n. Por. A. Görres, Glaubensgewißheit in einer pluralistischen Welt, IKZ 12 (1983) s. 117-132, szczególnie s. 129. 
Rozważając kwestię decyzji o aborcji Ratzinger odwołuje się do badań psychologów, którzy zauważyli u kobiet zamierzających usunąć ciążę stłumienie uczuć matki. Nie nadają imienia swojemu dziecku, nie wyobrażają sobie jego twarzy i przyszłości. Ale te tłumione wyobrażenia często wracają później jako dręczące poczucie winy ${ }^{29}$. Cokolwiek doprowadziło do aborcji, może np. nacisk ze strony mężczyzn, uśmiercono ludzką istotę. Psychologowie mówią, jak głęboko ten czyn tkwi później w psychice matki. Zdaje sobie ona sprawę, kogo w sobie nosiła. Wyobraża sobie, kim byłoby dzisiaj jej dziecko, z którego mogłaby być dumna ${ }^{30}$. Benedykt dziękuje organizacjom zaangażowanym w obronę życia i pomagającym w psychicznym uzdrowieniu skrzywdzonych przez tragedię aborcji ${ }^{31}$.

Pisząc o nawróceniu Ratzinger wspomina, że nawet daleka od religijnej refleksji psychoterapia odkryła, iż niepokonane poczucie winy niszczy człowieka, a jego pokonanie nie jest możliwe bez jakiegoś wyznania tego, co było tłumione i raniło wnętrze ${ }^{32}$. Grzech nie jest więc jakimś żydowskim wynalazkiem, jak pisał Fryderyk Nietzsche, ale rzeczywistością realną dotykającą każdego człowieka.

W 1989 roku przewodniczył Ratzinger sympozjum w Rzymie na temat grzechu pierworodnego. Ważny referat wygłosił na nim monachijski psycholog A. Görres. Wskazuje on na skutki grzechu pierworodnego w dziedzinie struktur i funkcji psychicznych. U człowieka po tym grzechu występuje zakłócenie zdolności poznawczych. Pojawia się skłonność do błędu, zawodzi zdolność wnioskowania, występuje brak pewności i przeciwnie pozór pewności. Rozum i uwaga tracą z pola widzenia to, co Boskie. Dochodzić może nawet do rezygnacji z pytania o sens i prawdę. Zanika możliwość wzajemnego rozumienia się ludzi. Słabnie świadomość tego, co słuszne i niesłuszne. Dominacja miłości własnej rodzi liczne konflikty wynikające $z$ konkurujących ze sobą poglądów i dążeń. Pojawia się przesyt i nuda. Człowiek doświadcza frustracji, trudu, smutku, stresu. Przestaje akceptować swoją skończoność i ograniczoność. Odczuwa nieuzasadnione lęki. Jego egzystencja staje się przeniknięta obawą przed niebezpieczeństwami, troską o przyszłość, lękiem przed śmiercią. Zaczyna dominować postawa obronna i nieufność, postawy ucieczki, obrony i uniku. Pojawiają się nerwice i psychozy jako skutki bólu, lęku, poczucia winy i innych rodzajów zła. Przygasa radość życia i pogoda ducha. Dążenia przestają być

\footnotetext{
29 Por. J. Ratzinger, Europa Benedykta w kryzysie kultur, Częstochowa 2005, s. 86.

30 Por. Sól ziemi. Chrześcijaństwo i Kościót katolicki..., s. 176n.

31 Por. Ojciec Święty Benedykt XVI w Fatimie 12-13 maja 2010. Akt zawierzenia, modlitwy, homilie, przemówienia, Kraków 2010, s. 53n.

32 Por. J. Ratzinger, Formalne zasady chrześcijaństwa. Szkice do teologii fundamentalnej, Poznań 2009, s. 71.
} 
uporządkowane. Człowieka zaczyna fascynować to, co niedozwolone. Buntuje się przeciwko autorytetowi ${ }^{33}$.

Ratzinger dostrzega we współczesnej filozofii i psychologii ujęcia przedstawiające bardzo pesymistyczny obraz człowieka żyjącego w lęku odpowiadające protestanckiemu rozumieniu człowieka jako z natury grzesznika ${ }^{34}$. Także bardzo rozpowszechnione są tendencje do przemilczania rzeczywistości grzechu, ukazywania go przez psychologię jako złudzenia lub kompleksu ${ }^{35}$. Ciekawe jest zwrócenie uwagi na teologiczne źródła ujęć psychologicznych, a w szczególności sugestia dotycząca możliwego związku myśli Zygmunta Freuda z duchowością Reformacji. Wydaje się, że otwiera się tutaj ciekawa perspektywa badawcza.

\section{Uzdrawiająca moc wiary, modlitwy i sakramentów}

Wiara pomaga człowiekowi żyć. Odkryć radość w głębi cierpienia. Święty Franciszek, nawet wtedy gdy załamały się jego oczekiwania, gdy psychicznie i fizycznie znalazł się w mroku najciemniejszej nocy, potrafil chwalić Boga ${ }^{36}$.

Rozważając problematykę kryzysu modlitwy Ratzinger powołuje się nie tylko na św. Augustyna i jego zdanie o człowieku jako modlącym się do Boga, ale także na opinię Carla Gustava Junga ${ }^{37}$, który uważał, że źródłem wszelkich nerwic jest wypchnięcie Boga z centrum życia, a uzdrowienie może dokonać się tylko przez rozwiązanie tego problemu. Przeciwstawia Junga Freudowi, dla którego religia oznaczała nerwicę ${ }^{38}$.

W modlitwie zaangażowane są wszystkie wymiary ludzkiej psychiki. Nie można jej oceniać wyłącznie miarą racjonalnego rozumienia. W modlitwie jest miejsce na powtarzanie, milczenie, śpiew ${ }^{39}$. Gdy człowiek nie może nocą znaleźć spokoju, może modlić się na różańcu. Modlitwa ta kojąco wpływa na psychikę. Jej powtarzające się słowa uwalniają od dręczących myśliit ${ }^{40}$ W szczególny sposób

33 Por. A. Görres, Uwagi psychologiczne na temat grzechu pierworodnego i jego skutków, w: C. Schönborn, A. Görres, R. Spaemann, Grzech pierworodny w nauczaniu Kościoła. Głos psychologa, filozofa, teologa, Poznań 1997, s. 15-24.

34 Por. J. Ratzinger, Dogma und Verkündigung, München - Freiburg/Br. 1973, s. 167.

35 Por. idem, Na początku Bóg stworzyt... Cztery kazania o stworzeniu i upadku. Konsekwencje wiary w stworzenie, Kraków 2006, s. 67.

36 Por. idem, Stużyć prawdzie. Myśli na każdy dzień, Wrocław 2001, s. 308.

37 Carl Gustav Jung (†1961) szwajcarski psychiatra i psycholog, twórca psychologii głębi.

38 Por. J. Ratzinger, Dogma und Verkündigung, München - Freiburg/Br. 1973, s. 123. Por. C. G. Jung, Die Beziehungen der Psychotherapie zur Seelsorge, Zürich 1948, s. 16.

39 Por. idem, Święto wiary. O teologii mszy świętej, Kraków 2006, s. 29.

40 Por. Bóg $i$ świat. Wiara $i$ życie w dzisiejszych czasach. Z kardynatem Josephem Ratzingerem rozmawia Peter Seewald, Kraków 2001, s. 16. 
zachęca Ratzinger do modlitwy kapłanów. Podaje przykład kard. Faulhabera arcybiskupa Monachium, który każdego wieczoru z domownikami odmawiał Różaniec i jak mówił, modląc się miał wrażenie, jakby matka kładła na nim uspokajająco rękę, a jego wypełniała na nowo cisza i spokój. Psychoterapeuci nie mogliby wymyśleć lepszej formy odprężenia. Ale taka modlitwa może być rzeczywiście wyzwalająca tylko wtedy, gdy odmawiamy ją nie dla wyzwolenia, ale w pokornym zwróceniu się do Matki Pana ${ }^{41}$.

Autor wskazuje na potrzebę spowiedzi odwołując się także do psychologii i psychoterapii. Nasze cierpienie związane jest z ucieczką w urojenia o własnej niewinności, które zamykają nas na innych. Wyznanie własnej winy w sakramencie pokuty może stać się wyzwalającym doświadczeniem, w którym spada z nas ciężar przeszłości, a my czujemy się odmłodzeni mocą łaski Bożej, która czyni nasze serca czystymi ${ }^{42}$. Zanik zdolności dostrzegania winy czyni człowieka zatwardziałym i chorym wewnętrznie. Zdolność dostrzegania winy można udźwignąć tylko wtedy, gdy możliwe jest uzdrowienie, a ono dokonuje się poprzez rozgrzeszenie. Psychoterapia może pomóc człowiekowi w rozpoznaniu i usunięciu błędnych połączeń w strukturze psychicznej, ale nie może przezwyciężyć winy. Tutaj konieczny jest sakrament, moc pochodząca od Boga ${ }^{43}$.

Namaszczenie chorych pomaga także w sferze psychicznej. Jest wsparciem w przyjmowaniu cierpienia. Poprzez ten sakrament dokonuje się włączenie bólu i cierpienia w sakramentalną wspólnotę z Chrystusem. Chrystus ucząc mnie cierpienia i cierpiąc ze mną może stać się moim prawdziwym lekarzem uzdrawiającym chorobę mojej duszy ${ }^{44}$.

Psychologia pozwala w pewnej mierze odkryć potrzebę wiary, modlitwy i przyjmowania sakramentów, a także ich uzdrawiającą siłę. Ale też może redukować tę rzeczywistość widząc w niej przede wszystkim rytuały mające pomóc człowiekowi.

\section{Chrystus przynoszący Zbawienie}

Autor przypomina antropologiczną analizę Confessiones. Człowiek, który zagubił prawdę o sobie samym, odszedł od siebie, żyje w pustce, jest pozbawiony wolności. Zwycięski Chrystus ofiarowuje człowiekowi powrót do siebie.

$41 \quad$ Por. J. Ratzinger, Głosiciele Stowa i słudzy Waszej radości. Teologia i duchowość sakramentu święceń, Opera omnia t. XII, Lublin 2012, s. 387.

42 Por. ibidem, s. 393.

43 Por. Bóg $i$ świat..., s. 388.

44 Por. ibidem, s. 398n. 
Umożliwia budowanie domu, którym jest Kościół. Najbardziej właściwym mieszkaniem człowieka jest prawda ${ }^{45}$.

Komentując wydarzenie Wniebowstąpienia Pańskiego dostrzega Ratzinger w wielkiej radości uczniów wracających z Góry Oliwnej (Dz 24, 52) doświadczenie niepasujące zupełnie do naszej normalnej psychologii. Pożegnanie z Chrystusem, chociaż zawierało w sobie coś z triumfu i nadziei, mogło wiązać się z lękiem przed opuszczeniem, z cierpieniem z powodu braku ludzkiej bliskości, z obawą przed trudami przyszłego świadczenia o Chrystusie. Nie zrozumiemy tych słów o wielkiej radości, jeśli nie spojrzymy na radość męczenników: śpiew Maksymiliana Kolbe w bunkrze głodowym czy Polikarpa na stosie. Radość zwycięstwa Chrystusa dociera nie tylko do rozumu, ale może też udzielić się sercu i być naprawdę przyjętą. Wstępujący do nieba Pan błogosławi uczniów. Wychodzą oni z tego doświadczenia pobłogosławieni, a nie opuszczeni. Wniebowstąpienie Chrystusa podnosi obraz człowieka, ukazuje, że może on żyć na wysokości samego Boga. Stanowi rehabilitację człowieka. Ukazuje, że zhańbiony nie został człowiek wyszydzony, ale ten, który szydzi ${ }^{46}$. Spotkanie z Chrystusem czyni człowieka zdolnym do nowego życia.

Tylko ucieczka z więzienia wygodnych kłamstw, tylko przyjęcie krzyża prowadzi w krainę prawdziwego pokoju. Psychoterapia wie dzisiaj, że kompleks jest najgłębszym powodem choroby i że uzdrowienie następuje przez wydobycie na wierzch prawdy najglębszego bólu. Tyle że psychoterapia nie wie, co jest prawdą i czy w końcu prawda jest dobra ${ }^{47}$.

Komentując słowa Chrystusa, który żegnając się z uczniami i idąc na krzyż życzy im pokoju, Ratzinger odwołuje się do psychoterapii, która wskazuje drogę uzdrowienia poprzez prawdę bolesnego doświadczenia. Teolog nie ukrywa jednak granic psychoterapeutycznych technik.

Ratzinger stwierdza, że „każda chrystologia, której treścią nie jest rzeczywiste utożsamienie się Boga z człowiekiem, jest nieinteresująca od strony psychologicznej i historycznej" ${ }^{48}$. Wydaje się, że autor wskazuje tutaj, że prawda o Wcieleniu odsłania głębię prawdy o człowieku. Dzięki temu w Chrystusie staje się możliwa tożsamość człowieka z Bogiem a także z ludźmi.

45 Por. J. Ratzinger, Pielgrzymująca wspólnota wiary. Kościót jako komunia, Kraków 2003, s. $50 \mathrm{n}$.

46 Por. idem, Obrazy nadziei. Wędrówki przez rok kościelny, Poznań 1998, s. 47-49.

47 Idem, Stużyć prawdzie..., s. 103.

48 Idem, Tożsamość z Kościołem, „Collegium Polonorum” 1995/1996 nr 13, s. 99. 
Patrząc na postać Jezusa z Nazaretu Ratzinger odwołuje się do cenionego przez siebie Romano Guardiniego ${ }^{49}$. Przypomina znane sformułowanie swojego nauczyciela: Jezus „stoi ponad naszymi psychologiami..." ${ }^{50}$. Krytycznie ocenia liberalne spojrzenia na wydarzenie chrztu Jezusa, które interpretują je jako odkrycie szczególnej relacji do Boga i religijnego posłannictwa. Mimo pozorów erudycji takie opracowania nie opierają się na tekstach Pisma Świętego. W Piśmie Świętym Chrystus ukazuje się nam jako umiłowany Syn, a nie tylko genialny człowiek. I właśnie dlatego jest nam tak bardzo bliski, a nie nieskończenie odległy jako jednostka $z$ minionej epoki ${ }^{51}$. W dyskusji ze spojrzeniem liberalnym odwołuje się autor nie tylko do zasadniczej kwestii autentycznej interpretacji tekstów, ale także do kwestii znaczenia Chrystusa dla naszego życia, powołując się na myśl św. Augustyna.

Chrześcijańskie odkupienie z wiary próbuje się dziś zastąpić odkupieniem na drodze polityczno-ekonomiczno-socjalnej i na drodze psychologicznej. Ludzie szukają laickich spowiedników, którzy mają doprowadzić do ładu rozbite i puste ludzkie życie. Ale duszy ludzkiej nie można złożyć jak zegarka. Nie można jej uleczyć pomijając punkt odniesienia. Bóg stanowi punkt konstrukcyjny ludzkiej egzystencji. Jeśli więź z nim się rozpada, wtedy wszystko inne również się rozpada ${ }^{52}$.

Bardzo krytycznie ocenia Ratzinger modę w życiu konsekrowanym, szczególnie wśród kobiet, na psychologię i psychoanalizę. W jednej z katolickich bibliotek w Ameryce Południowej autor zauważył zastąpienie traktatów religijnych podręcznikami psychoanalizy. W ten sposób teologia ustąpiła miejsca bardzo powierzchownej psychologii. $Z$ wielkim zaufaniem powierzano się przypadkowym specjalistom. Prowadziło to do utraty tożsamości i osłabienia motywacji prowadzenia życia zakonnego. Psychologowie mogą co najwyżej powiedzieć, jak funkcjonują siły duchowe. Nie mogą jednak powiedzieć, dlaczego i w jakim celu. Już św. Augustyn przypomina o konieczności odniesienia duszy do Boga. Duchowość nie może pracować w próżni, bez ukierunkowania ${ }^{53}$. Autor krytykuje nie psychologię jako taką, ale rezygnowanie z zasadniczego dla chrześcijanina odniesienia do Chrystusa. Bez tego odniesienia życie chrześcijanina a tym bardziej osoby konsekrowanej traci sens.

49 Por. R. Guardini, Das Wesen des Christentums. Die menschliche Wirklichkeit des Herrn. Beiträge zu einer Psychologie Jesu, Mainz - Paderborn 1991.

50 J. Ratzinger/Benedykt XVI, Jezus z Nazaretu..., s. 34.

51 Por. ibidem, s. 34.

52 Por. J. Ratzinger, Stużyć prawdzie..., s. 83.

53 Por. idem, Raport o stanie wiary, Marki 2005, s. 88n. 
Osoba Jezusa Chrystusa przekracza możliwości badawcze psychologii. Prawda o przyjęciu ludzkiej natury przez Syna Bożego pozwala głębiej wejść w tajemnicę człowieka. Odsłania nowe perspektywy także przed psychologią. Wskazuje na możliwości człowieka, których nie był on nawet świadomy. Odchodzenie od Chrystusa oznacza wielkie zubożenie ludzkiego życia.

\section{Pokusa redukcjonizmu}

Rozważając kwestię liturgii niedzielnej bez kapłana, Ratzinger zwraca uwagę na priorytet sakramentu przed jakimkolwiek psychologizmem. Na terenach misyjnych, w diasporze, podczas prześladowania występują sytuacje niemożności uczestnictwa w niedzielnej Eucharystii. W obecnych czasach spadek powołań kapłańskich powoduje trudności także w krajach od dawna chrześcijańskich. Występuje pokusa stawiania na pierwszym miejscu doświadczenia wzajemnej bliskości i stąd organizowania świątecznego zgromadzenia bez kapłana w swoim kościele. Trzeba odróżnić tę sytuację od rzeczywistej konieczności sprawowania liturgii bez kapłana, gdy ludzie nie zamykając się w tym, co tylko ludzkie usiłują zaczerpnąc choćby cząstkę z rzeczywistości Dnia Pańskiego. Teoria, według której można w zasadzie sprawować liturgię tylko w znanej sobie wspólnocie i ze znanym kapłanem jest błędna i wskazująca na podporządkowanie kryteriów teologicznych socjologicznym i psychologicznym ${ }^{54}$. Rozważając myśl Durkheima ${ }^{55}$ Ratzinger stwierdza, że tylko wtedy, ,gdy sakrament zachowuje swą bezwarunkowość i absolutny priorytet przed wszelkimi celami społecznymi oraz przed wszelkimi intencjami duchowo «budującymi», tworzy także społeczność i «buduje» człowieka" ${ }^{56}$. Pozytywny wpływ sakramentu na życie psychiczne i społeczne człowieka jest możliwy wtedy, gdy człowiek otwiera się na rzeczywistość przychodzącą z góry i zachowuje hierarchię ważności.

Autor dostrzega pokusę uwspółcześnienia chrześcijaństwa poprzez przekształcenie go w polityczny moralizm lub psychoterapię. Ten drugi projekt pragnie przedstawić religię jako miejsce osiągania możliwie całościowego dobrego samopoczucia. Zapomina się o źródłach, o wierze, a próbuje realizować własne projekty, które nie są w stanie ustanowić wspólnoty z Bogiem ani trwałej więzi między ludźmi ${ }^{57}$.

54 Por. J. Ratzinger, Znaczenie Dnia Pańskiego, „Communio” 1995 nr 3, s. 54 - 58.

55 Émile Durkheim $(† 1917)$ francuski socjolog, filozof, etnolog. Ratzinger powoluje się tutaj na myśl Durkheima redukującą religię i kult do ogólnej formy stabilizacji społecznej, która jednak przestaje funkcjonować z chwilą uświadomienia sobie takiego jej charakteru.

56 Ibidem, s. 56.

57 Por. Benedykt XVI w rozmowie z Peterem Seewaldem, Świattość świata. Papież, Kościót i znaki czasu, Kraków 2011, s. 149. 
Przed kapłanem pojawia się pokusa stawania się pracownikiem socjalnym, który doradza ludziom na podstawie osobistego doświadczenia i wiedzy psychologicznej czy socjologicznej. Warto na nowo odkryć wartość posługi kapłańskiej, która jest czymś o wiele większym. Jest ofiarowaniem człowiekowi tego, co może dać Pan ${ }^{58}$.

Ratzinger krytycznie odnosi się do prac Eugena Drewermanna, czołowego przedstawiciela egzegezy opartej na psychologii głębi. Tym niemniej przyznaje w pewnej mierze słuszność twierdzeniom Junga i Drewermanna o religiach jako systemach psychoterapeutycznych. Religia rzeczywiście zawiera w sobie lecznicze siły. Daje odpowiedź na ludzkie potrzeby i lęki. Nie można jej jednak redukować do leczniczego działania. Jest ona czymś więcej. Jej istotę stanowi odniesienie człowieka ku tej nieznanej rzeczywistości, którą wiara nazywa Bogiem $^{59}$. Ratzinger uznaje słuszność krytyki Drewermanna wobec egzegezy historyczno-krytycznej jako jedynej metody badawczej. Egzegeza ta nie mówi o chwili obecnej, o mnie, ale o dniu wczorajszym, o innych. Nie przenosi Biblii w moje obecne życie. Nie ukazuje Chrystusa dzisiejszego, ale z wczoraj ${ }^{60}$. Oczywiście ocena Ratzingera interpretacji Pisma Świętego przy pomocy psychologii głębi jest zdecydowanie krytyczna. Autor widzi tutaj próbę sprowadzenia Biblii do mitycznych archetypów wskazujących człowiekowi drogę do uzdrawiającego schodzenia w głębokie pokłady duszy. Przyjmowanie takich prób interpretacji jest znakiem poważnego kryzysu współczesnej teologii ${ }^{61}$.

Ratzinger podkreśla specyfikę teologii. Różni się ona od innych nauk humanistycznych. Posiada pewność, która nie jest pewnością hipotezy, o którą można się spierać, ale pewność, na której można oprzeć swoje życie. Jest to możliwe dzięki związkowi teologii z Kościołem, dzięki istnieniu Urzędu Nauczycielskiego ${ }^{62}$.Zwraca uwagę na wyjątkowość teologii, jej specyfikę, a równocześnie na pewną pokusę redukowania teologii do historii, psychologii, socjologii czy filozofii chrześcijaństwa. Bardzo wyraźnie krytykuje naiwną wiarę w naukę w teologii posoborowej.

Ta wiara traktuje nauki humanistyczne jak nową ewangelię i nie chce widzieć granic, poza które te nauki nie sięgają, ani trudności, które ze sobą niosą. Psychologia,

58 Por. J. Ratzinger, Zeitfragen und christlicher Glaube. Acht Predigten aus der Münchener Jahren, Würzburg 1982, s. 84n.

59 Por. Sól ziemi. Chrześcijaństwo i Kościót katolicki na przełomie tysiacleci. Z kardynałem Josephem Ratzingerem rozmawia Peter Seewald, Kraków 2005, s. 18.

60 Por. J. Ratzinger, Wiara - prawda - tolerancja. Chrześcijaństwo a religie świata, Kielce 2005, s. 108.

61 Por. idem, Stowo Boga. Pismo - Tradycja-Urzą, Kraków 2008, s. 93, 140. Por. G. Lohfink, R. Pesch, Tiefenpsychologie und keine Exegese, Stuttgart 1987.

62 Por. J. Ratzinger, Prawda w teologii, Kraków 2005, s. 50n. 
socjologia i marksistowska interpretacja historii zostały uznane za naukowo pewne, a zatem za niekwestionowane instancje myśli chrześcijańskiej63.

Według Ratzingera, zadaniem czasopisma „Communio” jest ukazywanie Kościoła we właściwym tego słowa znaczeniu, Kościoła z wysoka. Ta perspektywa znika z pola widzenia w myśleniu czysto socjologicznym i psychologicznym. „Communio” powinno przede wszystkim pogłębiać głoszenie tajemnicy Boga. Musi także rozwijać antropologię. Uczynić Słowo Boże odpowiedzią daną człowiekowi ${ }^{64}$. Szacunek dla psychologii nie może oznaczać bezkrytycznego podejścia do jej wyników i metod.

Rozważając doświadczenie Boga autor zwraca uwagę, że to doświadczenie powinno nas kierować ku samemu Bogu, który jest zawsze większy. Gdy zatrzymujemy się na samym doświadczeniu, obracamy się w kręgu naszej własnej psychologii 65 .

We współczesnym świecie Kościół staje wobec pokusy redukcjonizmu. Dotyczyć może ona zarówno liturgii czy działalności duszpasterskiej jak egzegezy czy teologii. Mogą utracić one swoją tożsamość.

\section{Podsumowanie}

Ratzinger w szczególny sposób zna i ceni św. Augustyna, tego z Ojców Kościoła, który szczególnie badał wnętrze człowieka, świat jego przeżyć. Współpracuje i korzysta z refleksji Alberta Görresa wybitnego niemieckiego psychologa XX wieku. Powołuje się na prace C. G. Junga. Broniąc prawdy o stworzeniu broni znaczenia sfery ludzkiej psychiki. Wskazując na rzeczywistość ludzkiego grzechu i poczucia winy odwołuje się także do badań psychologów. Podkreśla uzdrawiającą moc wiary, modlitwy i sakramentów świętych. Wyraża troskę o człowieka chorego psychicznie, który jest uprzywilejowanym dzieckiem Stwórcy. Zachęca do ekologii psychicznej. Podkreśla specyfikę teologii, której nie można zredukować do nauk humanistycznych. Sakrament może pozytywnie wpływać na życie psychiczne człowieka tylko wtedy, gdy zachowuje swój priorytet. Przede wszystkim jednak autor podkreśla prawdę o Chrystusie przynoszącym zbawienie człowiekowi. Zbawienia nie da się osiągnąć na drodze psychologicznej pomijając Boga, który jest punktem konstrukcyjnym ludzkiej egzystencji.

Słowa klucze: teologia, psychologia, antropologia, J. Ratzinger, Benedykt XVI.

\footnotetext{
63 J. Ratzinger, Raport o stanie wiary, Marki 2005, s. 158.

64 Por. idem, Communio - program, „Communio” 1992 nr 5, s. 13n.

65 Por. idem, Doświadczenie a wiara, „Communio” 1981, nr 4, s. 19.
} 


\section{Bibliografia:}

1. Benedykt XVI, Katechezy o Ojcach Kościoła, Kraków 2008.

2. Benedykt XVI, Adhortacja Africae munus.

3. Benedykt XVI, Spe salvi.

4. Benedykt XVI w rozmowie z Peterem Seewaldem, Świattość świata. Papież, Kościót $i$ znaki czasu, Kraków 2011.

5. Bóg $i$ świat. Wiara $i$ życie w dzisiejszych czasach. Z kardynałem Josephem Ratzingerem rozmawia Peter Seewald, Kraków 2001

6. Cyprian z Kartaginy, De dominica oratione, w: Thasci Caecilli Cypriani Opera omnia, CSEL III 1.

7. Görres A., Glaubensgewißheit in einer pluralistischen Welt, IKZ 12 (1983).

8. Görres A., Uwagi psychologiczne na temat grzechu pierworodnego i jego skutków, w: C. Schönborn, A. Görres, R. Spaemann, Grzech pierworodny w nauczaniu Kościoła. Głos psychologa, filozofa, teologa, Poznań 1997.

9. Guardini R., Das Wesen des Christentums. Die menschliche Wirklichkeit des Herrn. Beiträge zu einer Psychologie Jesu, Mainz - Paderborn 1991.

10. Jung C. G., Die Beziehungen der Psychotherapie zur Seelsorge, Zürich 1948.

11. Lohfink G., Pesch R., Tiefenpsychologie und keine Exegese, Stuttgart 1987.

12. Maier H., Getto emancypacji - przeczytane ponownie, w: J. Ratzinger, H. Maier, Demokracja w Kościele. Możliwości i ograniczenia, Kraków 2004.

13. Ojciec Święty Benedykt XVI w Fatimie 12-13 maja 2010. Akt zawierzenia, modlitwy, homilie, przemówienia, Kraków 2010.

14. Ratzinger J., Brücke der Einheit und Versöhnung. Pfingstpredigt beim Gottesdienst zum Sudetendeutschen Tag in München am 3.6.1979, München 1979.

15. Ratzinger J., Communio - program, „Communio” 1992 nr 5.

16. Ratzinger J., Dogma und Verkündigung, München - Freiburg/Br. 1973.

17. Ratzinger J., Doświadczenie a wiara, „Communio” 1981, nr 4.

18. Ratzinger J., Europa Benedykta w kryzysie kultur, Częstochowa 2005.

19. Ratzinger J., Formalne zasady chrześcijaństwa. Szkice do teologii fundamentalnej, Poznań 2009.

20. Ratzinger J., Głosiciele i studzy Waszej radości. Teologia i duchowość sakramentu święceń, Opera omnia t. XII, Lublin 2012.

21. Ratzinger J., Gottes Projekt. Nachdenken über Schöpfung und Kirche, Regensburg 2009.

22. Ratzinger J., Moje życie. Wspomnienia z lat 1927-1977, Częstochowa 1998.

23. Ratzinger J., Na początku Bóg stworzyt...Cztery kazania o stworzeniu $i$ upadku. Konsekwencje wiary w stworzenie, Kraków 2006.

24. Ratzinger J., Obrazy nadziei. Wędrówki przez rok kościelny, Poznań 1998.

25. Ratzinger J., Pielgrzymująca wspólnota wiary. Kościót jako komunia, Kraków 2003.

26. Ratzinger J., Prawda i sumienie, „Ethos” 4(1991) nr 3/4

27. Ratzinger J., Prawda w teologii, Kraków 2005.

28. Ratzinger J., Przekaz wiary i źródta wiary, „Więź” 1984 nr 2/3.

29. Ratzinger J., Raport o stanie wiary, Marki 2005.

30. Ratzinger J., Stowo Boga. Pismo - Tradycja - Urzad, Kraków 2008.

31. Ratzinger J., Stużyć prawdzie. Myśli na każdy dzień, Wrocław 2001. 
32. Ratzinger J., Święto wiary. O teologii mszy świętej, Kraków 2006.

33. Ratzinger J., Tożsamość z Kościołem, „Collegium Polonorum” 1995/1996 nr 13.

34. Ratzinger J., Wiara - prawda - tolerancja. Chrześcijaństwo a religie świata, Kielce 2005.

35. Ratzinger J., W drodze do Jezusa Chrystusa, Kraków 2004.

36. Ratzinger J., Zeitfragen und christlicher Glaube. Acht Predigten aus der Münchener Jahren, Würzburg 1982.

37. Ratzinger J., Znaczenie Dnia Pańskiego, „Communio” 1995 nr 3.

38. Ratzinger J. / Benedykt XVI, Jezus z Nazaretu, cz. 1, Od Chrztu w Jordanie do Przemienienia, Kraków 2007.

39. Ryn Z. J., Na obraz i podobieństwo Boże - czy zawsze?, „L'Osservatore Romano” $1997 \mathrm{nr} 3$.

40. Sól ziemi. Chrześcijaństwo i Kościót katolicki na przełomie tysiacleci. Z kardynatem Josephem Ratzingerem rozmawia Peter Seewald, Kraków 2005.

41. Szymik J., Theologia Benedicta, t. II, Katowice 2012. 